\begin{abstract}
Iranica
Abstracta Iranica Revue bibliographique pour le domaine irano-aryen

Volume 40-41 | 2019

Comptes rendus des publications de 2017-2018
\end{abstract}

\title{
Nikolaus Schindel. „Eine neue sasanidische Münzstätte?"
}

\section{Rika Gyselen}

\section{(2) OpenEdition \\ 1 Journals}

\section{Édition électronique}

URL : http://journals.openedition.org/abstractairanica/49640

DOI : 10.4000/abstractairanica.49640

ISBN : 1961-960X

ISSN : 1961-960X

Éditeur :

CNRS (UMR 7528 Mondes iraniens et indiens), Éditions de l'IFRI

Référence électronique

Rika Gyselen, « Nikolaus Schindel. „Eine neue sasanidische Münzstätte?" », Abstracta Iranica [En ligne], Volume 40-41 | 2019, document 25, mis en ligne le 30 octobre 2019, consulté le 20 avril 2021. URL : http://journals.openedition.org/abstractairanica/49640; DOI : https://doi.org/10.4000/ abstractairanica. 49640

Ce document a été généré automatiquement le 20 avril 2021.

Tous droits réservés 


\title{
Nikolaus Schindel. „Eine neue sasanidische Münzstätte?“
}

\author{
Rika Gyselen
}

\section{RÉFÉRENCE}

Nikolaus Schindel. „Eine neue sasanidische Münzstätte?“ [Un nouvel atelier monétaire sassanide ?], Mitteilungen der Österreichischen Numismatischen Gesellschaft 57/2, 2017, p. $116-122$

1 Deux monnaies de l'an du règne 5 de Husraw Ier, frappées par le même coin de revers, portent un sigle monétaire non attesté jusqu'à présent que l'A. lit KYŠ. Il passe en revue les toponymes qui sont constitués ou commencent par ces lettres sans pouvoir proposer une identification convaincante.

\section{AUTEURS}

RIKA GYSELEN

CNRS, Mondes iranien et indien 